\title{
Effectiveness of binary combinations of Plectranthus glandulosus leaf powder and Hymenocardia acida wood ash against Sitophilus zeamais (Coleoptera: Curculionidae)
}

\author{
Jean Wini Goudoungou ${ }^{1 *}$, Elias Nchiwan Nukenine ${ }^{2}$, Christopher Suh³ ${ }^{3}$ Tiburce Gangué
} and Dieudonné Ndjonka²

\begin{abstract}
Background: Botanicals are generally assumed to be more biodegradable, leading to less environmental problems. Combination of botanicals could enhance biological activity against insect pests. Hence, the amount of botanical used for the control of stored grain pests may be minimised. In this study, the bioassay was carried out on Sitophilus zeamais to assess the effectiveness of binary combinations of Hymenocardia acida wood ash and Plectranthus glandulosus leaf powder. The quantities of mixed products were added to maize grains to constitute the contents of 5, 10, 20 and $40 \mathrm{~g} / \mathrm{kg}$. Then, the bioassays on toxicity within 1, 3,7 and 14 days exposure, progeny production, population increase, grain damage and germination ability of protected grains were carried out.

Results: The major compounds (pinene, a-pinene, a-terpineol, thymol, $\beta$-myrcene and 3-carene) of P. glandulosus leaf powder were monoterpenes. The major non-monoterpenic constituent was an oxygenated sesquiterpene, $\beta$ caryophyllene oxide. The chemical analysis of $\mathrm{H}$. acida ash showed that calcium $(5800 \mathrm{mg} / \mathrm{kg}$ ) and phosphorus (2782 mg/kg) recorded higher content than the other minerals. Plectranthus glandulosus leaf powder, H. acida wood ash and their binary combinations significantly induced mortality of $S$. zeamais adult $(P<0.0001)$. The higher mortality rate was achieved by the highest content within 14 days of exposure. The combinations of $P$. glandulosus leaf powder with $\mathrm{H}$. acida at different proportions produced different interactions. The mixture of $75 \% \mathrm{P}$. glandulosus and $25 \% \mathrm{H}$. acida produced synergistic effect, whereas the mixture of 50:50 had antagonistic effect in weevil mortality. The three combinations of $\mathrm{H}$. acida and P. glandulosus significantly reduced the production of the progeny compared to the control. From the application of $5 \mathrm{~g} / \mathrm{kg}$ (lowest content), the number of emerging adults was highly reduced. The combination 25PG75HA revealed to be more effective than the two other against $F_{1}$ production. The grain damage and population growth were significantly reduced. In general, the non-infested maize grain had a good germination rate than the infested ones. The treatment did not have negative effect on seed germination.
\end{abstract}

Conclusions: From our results, the two powders and their binary combinations could be used to reduce grain infestation by insect while taking into account the proportions of insecticidal powders implied in the combination.

Keywords: Sitophilus zeamais, Hymenocardia acida, Plectranthus glandulosus, Wood ash, Leaf powder, Binary combinations

\footnotetext{
*Correspondence: winigoudoungou@yahoo.fr

${ }^{1}$ Department of Biological Sciences, Faculty of Science, University

of Bamenda, P.O. Box 39, Bambili, Cameroon

Full list of author information is available at the end of the article
} 


\section{Background}

Cereals constitute the group of most consumed grain in sub-Saharan African, especially in Sahelian zones. In these zones, cereals are very interesting according to its conservation ability. Cereals are easily conserved compared to the other food products and also less demanding in terms of storage technology, which can be self-made. The conserved and protected seeds permit availability of seeds (food) throughout the year, thereby contributing to food security. Cereals such as sorghum, millets, wheat, maize and rice are major staple foods of most population. Botanically, cereals are grasses and belong to the monocot family Poaceae [1]. Maize remains the most cultivated and most consumed cereal in Africa. This staple food crop is grown in diverse agro-ecological zones and farming systems, and consumed by people with varying food preferences and socio-economic backgrounds in subSaharan Africa. Maize also has many uses in food industry (biscuit factory, pastry making, brewery, distilling, sweetening substance, etc.), textile industry, utilisation in pharmaceutical industry, biodegradable plastics, biofuel, alcohol and cosmetics production [2]. The production of maize is done in the short period of the year, whereas its commercialisation and consumption are done all year round. This makes imperative the storage and the protection of this grain. The insufficiencies of different storage methods in developing countries have not stopped to cause grain losses and this in unacceptable proportions [3].

During storage, maize grain is highly devastated by several pests, especially insect pest. Insects are at the origin of the majority of the damage occurring in the reserves of stored food products. Temperature and high humidity of the tropical climate favour proliferation of insects and micro-organisms which, in order to survive, devour the food products causing enormous damage [4]. Maize grain does not escape to insect attack during storage. Amongst the insect, maize grain pest, Sitophilus zeamais is the most detrimental. This pest causes quantitative and qualitative damage on stored maize. In this condition, the protection of this grain according to its multiple uses becomes a major necessity of food security. Food security could be enhanced by reducing stock losses. Damage caused by $S$. zeamais on maize could be reduced through chemical, biological, physical control and host plant resistance, which are important components of integrated pest management strategies. However, the use of synthetic residual chemicals dominates in Cameroon and other African countries. These chemicals, although effective, cause many environmental problems such as pollution, diseases and resistance in pests $[5,6]$. Furthermore, the majority of farmers in Africa are resourcepoor and have neither the means nor the skills to obtain and handle pesticides appropriately. Therefore, an environmentally safe and economically feasible pest control practice needs to be available.

Botanicals are products based on parts, powders, extracts or purified substances of plant origin. They are generally assumed to be more biodegradable, leading to less environmental problems. Plectranthus glandulosus Hook leaf [7-9] and wood ash [10-13] could stand out as good candidates for environmentally friendly control of storage beetle pests under Cameroonian conditions. $P$. glandulosus is an annual, glandular and strongly aromatic herb, used in folk medicine for the treatment of colds and sore throat in the Adamawa region of Cameroon [14]. The insecticidal properties of products from P. glandulosus have shown good insecticidal properties against stored maize grain pests $[8,9,15-17]$. The leaf powder of the plant, which is more accessible to rural farmers than synthetic chemicals, should be an alternative to control the different stages of insect pests. Many authors have reported the effectiveness of wood ash as a grain protectant [18-22]. The insecticidal efficacy of Hymenocardia acida wood ash needs to be determined since it is one of the plants which the wood is most used as firewood and charcoal in traditional kitchens in the northern part of Cameroon. Combinations of wood ash with P. glandulosus leaf powder could enhance biological activity against insects. This in turn will reduce the amount of both botanical and wood ash used in storage protection. Data concerning the effectiveness of the binary combinations between $H$. acida wood ash and P. glandulosus leaf powder are not available, although farmers mix dusts like wood ash with plant materials in stocks. As the stored grain in traditional facilities is used as seeds, the determination of the influence of grain protectant on seed germination is imperative.

Therefore, the objective of this study was to assess the effectiveness of binary combinations between $P$. glandulosus leaf powder and $H$. acida wood ash regarding adult toxicity, progeny production, population growth, grain damage and germination.

\section{Methods}

\section{Source of maize grains}

The variety of maize used during all experimentation was Shaba provided by IRAD, Wakwa station in the Adamawa region of Cameroon. Before experimentation, broken grains, the pieces of stone, sand and other foreign materials were removed from the stock. Then, the maize was kept in the freezer at $-20^{\circ} \mathrm{C}$ for 14 days to allow its disinfestations. After disinfestations from all types of living organisms, the maize was kept in ambient conditions of laboratory for 14 days to allow its acclimatisation. After 
all these steps, the maize was ready for use as substrate for insect rearing and bioassays.

\section{Insect rearing}

Adults of $S$. zeamais were obtained from a colony maintained in rearing since 2005 in the Applied Chemistry Laboratory of the University of Ngaoundere. Then, the insect culture was transferred and kept in Crop Protection Laboratory of IRAD Bambui, North-West region of Cameroon. The weevils were reared on disinfested maize in $900-\mathrm{mL}$ glass jars and kept under laboratory conditions $\left(23.08 \pm 2.05^{\circ} \mathrm{C}\right.$ and $74.67 \pm 14.36 \%$ r.h.). The culture was maintained and used as source of $S$. zeamais for bioassays.

\section{Preparation of Hymenocardia acida wood ash}

Stems and branches of $H$. acida were collected in Ngaoundéré, Adamawa region of Cameroon (latitude $7^{\circ} 25^{\prime}$ North and longitude $13^{\circ} 35^{\prime}$ East, altitude of $1151 \mathrm{~m}$ above sea level). The identity of the plants was confirmed at the Cameroon National Herbarium in Yaounde, where voucher samples were deposited. $H$. acida is registered on number $50114 / \mathrm{HNC}$. Woods were air-dried until moisture was completely lost and burnt separately in a traditional kitchen normally used in the region. The obtained ash was sieved and packaged in glass jars, labelled and kept in a freezer $\left(\right.$ at $\left.-4{ }^{\circ} \mathrm{C}\right)$ until subsequent use in the bioassays.

\section{Preparation of Plectranthus glandulosus leaf powder}

Leaves of $P$. glandulosus were collected in July 2012 in Ngaoundere, head quarter of the Adamawa region of Cameroon (latitude $7^{\circ} 25^{\prime}$ North and longitude $13^{\circ} 35^{\prime}$ East, altitude of $1151 \mathrm{~m}$ above sea level). The identity of the plant was confirmed at the Cameroon National Herbarium in Yaounde on number 7656/SRF. The leaves were dried at room temperature for 7 days and then crushed. The crushed leaves were ground until the powder passed through a $0.20-\mathrm{mm}$ sieve. Then, a part of powder was stored in a freezer at $-20{ }^{\circ} \mathrm{C}$ until needed for bioassays and the other part was used for essential oil extraction.

\section{Preparation of binary combinations}

The products were mixed in the following proportions to constitute the different binary combinations:

- 25\% P. glandulosus leaf powder and $75 \%$ H. acida wood ash: 25PG75HA;

- 50\% P. glandulosus leaf powder and 50\% H. acida wood ash: 50PG50HA;

- $75 \%$ P. glandulosus leaf powder and 25\% H. acida wood ash: 75PG25HA.
Analysis of volatile compounds of Plectranthus glandulosus leaf powder

The essential oil was extracted by hydrodistillation during $4 \mathrm{~h}$ using a Clevenger-type apparatus. The extracted oil was kept in a brown bottle at $4{ }^{\circ} \mathrm{C}$ to avoid degradation of chemical compounds by light until needed for gas chromatography-mass spectrometry (GC-MS) analysis.

Gas chromatography-mass spectrometry analysis was carried out with a chromatograph, model Agilent 7890A GC, equipped with an automatic injector and a column HP-1MS $(15 \mathrm{~m} \times 0.25 \mathrm{~mm}$ d.i; $0.25 \mu \mathrm{m}$ film thickness) coupled to a mass detector Agilent 7890A MSD. The molecules were bombarded by an electronic beam of $70 \mathrm{eV}$. The gaze vector was helium $(1 \mathrm{~mL} / \mathrm{min})$ with a pressure of $25 \mathrm{psi}$ at the beginning of the column. The injector temperature was $250{ }^{\circ} \mathrm{C}$. The programming of temperature consisted of a rise from 60 to $230{ }^{\circ} \mathrm{C}$ with the range of $2{ }^{\circ} \mathrm{C} / \mathrm{min}$ and then $35^{\circ} \mathrm{C} / \mathrm{min}$ to reach $230{ }^{\circ} \mathrm{C}$. The injection was done by split mode with the coefficient of $1 / 180$. The injected quantity of essential oil of $P$. glandulosus was $0.2 \mu \mathrm{L}$. The detection was done by a quadripolar analyser constituted by an assembling of four parallel cylindrical electrodes. The bombing of essential oil by the electronic beam of $70 \mathrm{eV}$ induced its ionisation and its fragmentation. Then, the positive ionic fragments formed the characteristic mass spectrum of compounds. The obtained spectra were compared with computerised database using NIST/EPA/NIH Mass Spectral Library, Wiley Register of Mass Spectral Data [23] and König et al. [24].

\section{Determination of Hymenocardia acida wood ash mineral contents}

The sample of ash was calcinated at $450{ }^{\circ} \mathrm{C}$ for $24 \mathrm{~h}$ using incinerator for a complete mineralisation [25]. Calcinated ash was dissolved in nitric acid $\left(\mathrm{HNO}_{3}\right) 1 \mathrm{M}$ for digestion and then boiled. The solution was filtered after cooling. The filtrate obtained was used to proportion the following minerals: $\mathrm{P}, \mathrm{K}, \mathrm{Ca}, \mathrm{Mg}, \mathrm{Na}, \mathrm{Fe}, \mathrm{Mn}, \mathrm{Zn}$ and $\mathrm{Pb} . \mathrm{Ca}$, $\mathrm{K}$ and $\mathrm{Na}$ were proportioned by flame photometry, while $\mathrm{Mg}, \mathrm{Fe}, \mathrm{Mn}, \mathrm{Zn}$ and $\mathrm{Pb}$ were proportioned by atomic absorption spectrometry. The content of phosphate was measured by molecular absorption spectrophotometry.

\section{Toxicity bioassay}

The toxicity bioassay was carried out under ambient conditions of the laboratory. During experimentation, the temperature and relative humidity were recorded using a data logger (Data logger Model EL-USB-2, LASCAR, China). Four concentrations from each combination were considered. The masses of $0.25,0.5,1$ and $2 \mathrm{~g}$ of $P$. glandulosus leaf powder and $H$. acida wood ash as well as their binary combinations were separately added to 
$50 \mathrm{~g}$ of maize in glass jars to constitute the contents of 5, 10,20 and $40 \mathrm{~g} / \mathrm{kg}$, respectively. The insecticidal materials plus grain were thoroughly mixed by manual shaking. The controls consisted of substrate without insecticidal products. A group of 20 insects of mixed sexes and 7to 14-days-old were added into each jar containing the treated or untreated grains. All treatments were replicated four times, and the experiment was arranged in a completely randomised design. Mortality was recorded 1 , 3,7 and 14 days post-infestation.

The co-toxicity coefficient per $P$. glandulosus leaf powder- $H$. acida wood ash mixture was calculated: A co-toxicity coefficient of less than 80 is considered as antagonistic, between 80 and 120 as additive and higher than 120 as synergistic [26]. When mixture $(M)$ compounds of two parts $(A$ and $B)$ and both components have $\mathrm{LC}_{50}$, then the following formulae are used ( $A$ serving as standard, it is represented in this study by $P$. glandulosus leaf powder, $B$ represents wood ash for $H$. acida):

Toxicity index (TI) of $A=100$,

Toxicity index (TI) of $B=\frac{\mathrm{LC}_{50} \text { of } A}{\mathrm{LC}_{50} \text { of } B} \times 100$,

$$
\begin{aligned}
& \text { Actual TI of } M=\frac{\mathrm{LC}_{50} \text { of } A}{\mathrm{LC}_{50} \text { of } M} \times 100, \\
& \text { Theoretical TI of } \begin{array}{r}
M= \\
\text { TI of } A \times \% \text { of } A \text { in } M \\
+T I \text { of } B \times \% \text { of } B \text { in } M,
\end{array}
\end{aligned}
$$

Co-toxicity coefficient $=\frac{\text { Actual TI of } M}{\text { Theoretical TI of } M} \times 100$.

If one component of the mixture alone (for example a wood ash) causes low mortality at all doses $(<20 \%)$, then the co-toxicity coefficient of the mixture should be calculated by the formula:

Co-toxicity coefficient $=\frac{\mathrm{LC}_{50} \text { of } A \text { alone }}{\mathrm{LC}_{50} \text { of } A \text { in the mixture }} \times 100$.

\section{$F_{1}$ progeny bioassay}

After the 14-day mortality recordings, all insects and products were discarded. The grains were left inside the bottles, and the counting of $F_{1}$ adults was carried out once a week during 5 weeks. The emergence started only from 5 th week after infestation. After each counting session, the insects were removed from the jars [8].

\section{Damage bioassay}

Four rates of the binary combinations $(5,10,20$ and $40 \mathrm{~g} /$ $\mathrm{kg}$ ) were mixed with $150 \mathrm{~g}$ of maize grain as described above. Fifty unidentified sex weevils (7-14 days old) were introduced into each jar. Each treatment had four replications. After 3 months, the live weevils and dead ones were counted. Damage assessment was performed by counting and weighing the number of damaged and undamaged grain using the method of Adams and Schulten [27].

$$
\text { Weight loss }(\%)=\frac{\left(W_{\mathrm{u}} \times N_{\mathrm{d}}\right)-\left(W_{\mathrm{d}} \times N_{\mathrm{u}}\right)}{W_{\mathrm{u}}\left(N_{\mathrm{d}}+N_{\mathrm{u}}\right)} \times 100,
$$

where $W_{\mathrm{u}}$ is the weight of undamaged grain, $N_{\mathrm{d}}$ the number of damaged grain, $W_{\mathrm{d}}$ the weight of damaged grain, and $N_{\mathrm{u}}$ the number of undamaged grain.

\section{Test of germination}

Seed germination was tested using 30 randomly picked grains from non-perforated grains after separation of the perforated from the non-perforated in each jar. In order to assess the effect of binary mixtures on germination ability, the seeds were treated with different contents and stored as previously described, but without insect. The seeds from the two lots (infested and non-infested) of stored maize grains were placed on moistened paper in 9-cm glass Petri dishes. The number of germinated seeds was recorded after 10 days [28].

\section{Data analysis}

Abbott's formula [29] was used to correct for control mortality before analysis of variance (ANOVA) and probit analysis. Data on cumulative corrected mortality, reduction in $F_{1}$ progeny, damage, weight loss and germination percentage were arcsine-transformed [(square $\operatorname{root}(x / 100)]$, and the number of $\mathrm{F}_{1}$ progeny was logtransformed $(x+1)$. The transformed data were subjected to the ANOVA procedure using the statistical analysis system [30, 31]. Tukey's test $(P=0.05)$ was applied for mean separation. Probit analysis [31, 32] was conducted to determine lethal dosages causing $50 \%\left(\mathrm{LC}_{50}\right)$ and $95 \%$ $\left(\mathrm{LC}_{95}\right)$ mortality of $S$. zeamais at 1, 3, 7 and 14 days after treatment application. The probit analysis was also used to determine the effective content causing 50\% $\left(\mathrm{EC}_{50}\right)$ and $95 \%\left(\mathrm{EC}_{95}\right)$ reduction in $\mathrm{F}_{1}$ progeny.

\section{Results}

\section{Chemical analysis \\ Plectranthus glandulosus leaf powder}

The volatile constituents of the essential oils from $P$. glandulosus leaf powder were identified by their retention indices and mass spectra in comparison with those of standard synthetic compounds. The results of the chemical analysis are presented in Table 1 . The dominant chemical constituents were terpenic compounds. The major compounds were $\beta$-pinene (11.5\%), $\alpha$-pinene (11.2\%), $\alpha$-terpineol (10.8\%), thymol (10.1\%), $\beta$-myrcene $(9.7 \%)$ and 3 -carene $(8.7 \%)$, which are monoterpenes. The 
Table 1 Chemical constituents of essential oil of Plectranthus glandulosus leaf

\begin{tabular}{|c|c|}
\hline Compounds & $\%$ Composition \\
\hline \multicolumn{2}{|l|}{ Hydrocarbonated monoterpenes } \\
\hline 1R-a-Pinene & 11.2 \\
\hline$\beta$-Pinene & 11.5 \\
\hline$(+)$-4-Carene & 0.3 \\
\hline 3-Carene & 8.7 \\
\hline$\beta$-Phellandrene & $\operatorname{Tr}$ \\
\hline Paracymene & 7.5 \\
\hline Limonene & 2.5 \\
\hline$Y$-Terpinene & 0.1 \\
\hline$\beta$-Thujene & 0.2 \\
\hline 2-Methyladamantane & 0.8 \\
\hline (E)- $\beta$-Ocimene & 0.3 \\
\hline (E)-4,8-Dimethyl-1,3,7-nonatriene & $\operatorname{Tr}$ \\
\hline a-Terpinene & 1.3 \\
\hline$\beta$-Myrcene & 9.7 \\
\hline \multicolumn{2}{|l|}{ Hydrocarbonated sesquiterpenes } \\
\hline 7- $\beta$ - $[\mathrm{H}]$-silphiperfol-5-ene & 1.2 \\
\hline Silphin-1-ene & $\operatorname{Tr}$ \\
\hline Silphiperfola-5,7(14)-diene & 0.1 \\
\hline a-Copaene & 2.7 \\
\hline Pethybrene & 0.3 \\
\hline Modhephene & 0.3 \\
\hline a-Isocomene & 0.2 \\
\hline a-Curcumene & 0.2 \\
\hline Y-Gurjumene & $\operatorname{Tr}$ \\
\hline (Z,E)-a-Farnesene & 2.5 \\
\hline$\beta$-Selinene & 0.1 \\
\hline \multicolumn{2}{|l|}{ Oxygenated monoterpenes } \\
\hline a-Terpineol & 10.8 \\
\hline O-Acetylthymol & 0.8 \\
\hline Thymol & 10.1 \\
\hline (E,E)-2,4-Decadienal & 0.1 \\
\hline 8,9-Dihydrothymol & $\operatorname{Tr}$ \\
\hline Bornyl acetate & $\operatorname{Tr}$ \\
\hline Neryl acetate & 0.3 \\
\hline a-Terpenyle & 0.1 \\
\hline (E)- $\beta$-Damascenone & 0.4 \\
\hline$\beta$-Cyclocitral & 0.1 \\
\hline 4'-Methoxyvalerophenone & $\operatorname{Tr}$ \\
\hline p-Methoxycumene & $\operatorname{Tr}$ \\
\hline \multicolumn{2}{|l|}{ Oxygenated sesquiterpenes } \\
\hline Cubebol & $\operatorname{Tr}$ \\
\hline$\beta$-Caryophyllene oxide & 9.4 \\
\hline$\beta$-Oplopenone & $\operatorname{Tr}$ \\
\hline \multicolumn{2}{|l|}{ Aromatic compounds } \\
\hline 3,4-Xylenol & $\operatorname{Tr}$ \\
\hline 2-(2-Butynyl)-cyclohexanone & 0.1 \\
\hline Acetophenone & 5.5 \\
\hline
\end{tabular}

Table 1 continued

\begin{tabular}{ll}
\hline Compounds & \% Composition \\
\hline Aldehydes & \\
(E)-2-Nonanal & 0.1 \\
Undecanal & 0.2 \\
Decanal & 0.1 \\
Lauraldehyde & 0.1 \\
(E)-2-Decenal & 0.1 \\
Nonenal & 0.3 \\
Ketones & \\
Decan-2-one & $\mathrm{Tr}$ \\
Tridecan-2-one & $\mathrm{Tr}$ \\
Ester & \\
cis-hex-3-enyl-acetate & 0.5
\end{tabular}

Tr in trace $(<0.1)$

Table 2 Chemical composition of wood ash

\begin{tabular}{ll}
\hline Mineral & Content $\mathbf{( m g / k g )}$ \\
\hline Calcium & 5800 \\
Magnesium & 851 \\
Potassium & 997 \\
Sodium & 289 \\
Iron & 778 \\
Zinc & 786 \\
Lead & 0.0019 \\
Manganese & 0.011 \\
Phosphor & 2782 \\
\hline
\end{tabular}

major non-monoterpenic compound was an oxygenated sesquiterpene, $\beta$ caryophyllene oxide (9.4\%).

\section{Hymenocardia acida wood ash}

Different contents of ions were recorded concerning the mineral determination (Table 2). Calcium (5800 mg/ $\mathrm{kg})$ and phosphorus $(2782 \mathrm{mg} / \mathrm{kg})$ recorded the higher content than the other minerals. Iron, zinc and magnesium had almost the same content. The lower content was recorded for manganese $(0.011 \mathrm{mg} / \mathrm{kg})$ and lead $(0.0019 \mathrm{mg} / \mathrm{kg})$.

\section{Adult mortality}

Plectranthus glandulosus leaf powder, $H$. acida wood ash and their binary combinations induced significant mortality of $S$. zeamais adult (Table 3). This mortality increased with content and exposure time for each product (Table 4). The insecticidal efficacy varied slightly amongst the tested products. The higher mortality rate was achieved by the highest content $(40 \mathrm{~g} / \mathrm{kg})$ of $H$. acida wood ash (94.66\%) and 25PG75HA (94.59\%) within 
Table 3 Test of between-subjects effects concerning mortality

\begin{tabular}{|c|c|c|c|c|c|}
\hline Source & Sum of squares & $d f$ & Mean square & $F$ & Signification \\
\hline Product & 37794.240 & 4 & 9448.560 & 97.007 & $<0.0001$ \\
\hline Days after infestation & $97,723.529$ & 3 & $32,574.510$ & 334.436 & $<0.0001$ \\
\hline Content & $145,458.329$ & 4 & $36,364.582$ & 373.348 & $<0.0001$ \\
\hline Product $\times$ days after infestation & $18,876.462$ & 12 & 1573.039 & 16.150 & $<0.0001$ \\
\hline Product $\times$ content & $10,291.142$ & 16 & 643.196 & 6.604 & $<0.0001$ \\
\hline Days after infestation $\times$ content & $25,227.056$ & 12 & 2102.255 & 21.583 & $<0.0001$ \\
\hline Product $\times$ days after infestation $\times$ content & 6185.378 & 48 & 128.862 & 1.323 & 0.086 \\
\hline Error & $29,220.380$ & 300 & 97.401 & & \\
\hline Total & $857,756.358$ & 400 & & & \\
\hline
\end{tabular}

$d f$ degree of freedom

Table 4 Cumulative mortality of Sitophilus zeamais adult induced by Plectranthus glandulosus leaf powder, Hymenocardia acida wood ash and their binary combinations under fluctuating laboratory conditions (temp. $=22.76 \pm 2.02{ }^{\circ} \mathrm{C}$; r.h. $=69.87 \pm 9.93 \%)$

\begin{tabular}{|c|c|c|c|c|c|c|}
\hline \multirow[t]{2}{*}{ Content (g/kg) } & \multicolumn{5}{|l|}{ Products } & \multirow[t]{2}{*}{$F_{(4 ; 15)}$} \\
\hline & P. glandulosus & H. acida & 25PG75HA & 50PG50HA & 75PG25HA & \\
\hline \multicolumn{7}{|l|}{1 day } \\
\hline 0 & $0.00 \pm 0.00^{\mathrm{aA}}$ & $0.00 \pm 0.00^{\mathrm{cA}}$ & $0.00 \pm 0.00^{\mathrm{CA}}$ & $0.00 \pm 0.00^{\mathrm{CA}}$ & $0.00 \pm 0.00^{\mathrm{bA}}$ & - \\
\hline 5 & $3.82 \pm 2.41^{\mathrm{aB}}$ & $2.50 \pm 1.44^{\mathrm{bcB}}$ & $8.75 \pm 3.15^{\mathrm{bc} A B}$ & $11.25 \pm 1.25^{\mathrm{bAB}}$ & $21.25 \pm 5.91^{\mathrm{abA}}$ & $5.14^{*}$ \\
\hline 10 & $6.25 \pm 2.39^{a \mathrm{~B}}$ & $5.00 \pm 8.75^{\mathrm{abB}}$ & $22.50 \pm 4.33^{\mathrm{abAB}}$ & $20.00 \pm 2.04^{\mathrm{bAB}}$ & $28.75 \pm 6.57^{\mathrm{aA}}$ & $5.64^{*}$ \\
\hline 20 & $7.50 \pm 2.50^{\mathrm{aB}}$ & $8.75 \pm 1.25^{\mathrm{aB}}$ & $25.00 \pm 6.12^{\mathrm{abAB}}$ & $20.00 \pm 3.54^{\mathrm{bAB}}$ & $36.25 \pm 9.44^{\mathrm{aA}}$ & $6.82^{*}$ \\
\hline 40 & $16.25 \pm 5.91^{\mathrm{aAB}}$ & $12.50 \pm 1.44^{\mathrm{aB}}$ & $36.25 \pm 5.54^{\mathrm{aAB}}$ & $36.25 \pm 5.54^{\mathrm{aAB}}$ & $41.25 \pm 8.51^{\mathrm{aA}}$ & $5.04^{*}$ \\
\hline $\begin{array}{l}F_{(4 ; 15)} \\
3 \text { days }\end{array}$ & $2.48^{\mathrm{ns}}$ & $19.66^{* *}$ & $15.83^{* * *}$ & $40.80^{* * *}$ & $11.68^{* *}$ & \\
\hline 0 & $0.00 \pm 0.00^{\mathrm{CA}}$ & $0.00 \pm 0.00^{c A}$ & $0.00 \pm 0.00^{\mathrm{CA}}$ & $0.00 \pm 0.00^{\mathrm{bA}}$ & $0.00 \pm 0.00^{\mathrm{bA}}$ & - \\
\hline 5 & $6.25 \pm 3.15^{b c B}$ & $21.08 \pm 3.73^{\mathrm{bAB}}$ & $22.90 \pm 7.37^{\mathrm{bAB}}$ & $37.04 \pm 4.39^{\mathrm{aA}}$ & $25.06 \pm 4.10^{\mathrm{aA}}$ & $6.09^{*}$ \\
\hline 10 & $11.38 \pm 3.13^{\mathrm{abB}}$ & $24.57 \pm 1.99^{\mathrm{abAB}}$ & $42.17 \pm 7.18^{\mathrm{abA}}$ & $40.92 \pm 4.17^{\mathrm{aA}}$ & $38.82 \pm 7.98^{\mathrm{aA}}$ & $6.24^{*}$ \\
\hline 20 & $17.83 \pm 4.97^{\mathrm{aB}}$ & $33.66 \pm 2.01^{\mathrm{aAB}}$ & $44.42 \pm 5.58^{\mathrm{abA}}$ & $46.81 \pm 7.31^{\mathrm{aA}}$ & $40.07 \pm 7.87^{\mathrm{aAB}}$ & $3.95^{*}$ \\
\hline 40 & $21.58 \pm 3.87^{\mathrm{aB}}$ & $37.41 \pm 4.63^{\mathrm{aAB}}$ & $57.57 \pm 5.84^{\mathrm{aA}}$ & $56.45 \pm 6.18^{\mathrm{aA}}$ & $52.83 \pm 7.85^{\mathrm{aA}}$ & $7.02^{*}$ \\
\hline $\begin{array}{l}F_{(4 ; 15)} \\
7 \text { days }\end{array}$ & $12.10^{* * *}$ & $66.26^{* * *}$ & $28.53^{* * *}$ & $40.77^{* * *}$ & $22.16^{* * *}$ & \\
\hline 0 & $0.00 \pm 0.00^{\mathrm{CA}}$ & $0.00 \pm 0.00^{\mathrm{bA}}$ & $0.00 \pm 0.00^{\mathrm{bA}}$ & $0.00 \pm 0.00^{d A}$ & $0.00 \pm 0.00^{\mathrm{bA}}$ & - \\
\hline 5 & $7.77 \pm 2.59^{\mathrm{bB}}$ & $63.55 \pm 12.84^{\mathrm{aA}}$ & $36.55 \pm 10.94^{\mathrm{aAB}}$ & $43.71 \pm 3.25^{\mathrm{CAB}}$ & $36.92 \pm 3.14^{\mathrm{a} A \mathrm{~B}}$ & $5.89^{*}$ \\
\hline 10 & $14.15 \pm 3.21^{\mathrm{abB}}$ & $72.69 \pm 8.58^{\mathrm{aA}}$ & $53.15 \pm 9.47^{\mathrm{aA}}$ & $58.92 \pm 1.35^{\mathrm{bA}}$ & $49.27 \pm 5.36^{\mathrm{aA}}$ & $10.59^{* * *}$ \\
\hline 20 & $20.59 \pm 3.70^{\mathrm{abB}}$ & $77.96 \pm 8.65^{\mathrm{aA}}$ & $57.16 \pm 9.11^{\mathrm{aA}}$ & $69.72 \pm 5.31^{\mathrm{aA}}$ & $49.42 \pm 6.99^{\mathrm{aA}}$ & $11.63^{* * *}$ \\
\hline 40 & $28.16 \pm 4.73^{\mathrm{aC}}$ & $87.11 \pm 4.91^{\mathrm{aA}}$ & $68.35 \pm 4.40^{\mathrm{aAB}}$ & $76.76 \pm 1.02^{\mathrm{aA}}$ & $56.14 \pm 3.97^{\mathrm{aB}}$ & $27.67^{* * *}$ \\
\hline $\begin{array}{l}F_{(4 ; 15)} \\
14 \text { days }\end{array}$ & $16.00^{* * *}$ & $18.27^{* * *}$ & $21.54^{* * *}$ & $202.13^{* * *}$ & $57.03^{* * *}$ & \\
\hline 0 & $0.00 \pm 0.00^{\mathrm{dA}}$ & $0.00 \pm 0.00^{\mathrm{bA}}$ & $0.00 \pm 0.00^{\mathrm{CA}}$ & $0.00 \pm 0.00^{\mathrm{CA}}$ & $0.00 \pm 0.00^{\mathrm{cA}}$ & - \\
\hline 5 & $19.54 \pm 2.63^{\mathrm{CB}}$ & $69.08 \pm 10.78^{\mathrm{aA}}$ & $68.13 \pm 10.30^{\mathrm{bA}}$ & $63.16 \pm 5.27^{\mathrm{bA}}$ & $56.07 \pm 3.93^{\mathrm{bA}}$ & $7.87^{* *}$ \\
\hline 10 & $33.82 \pm 3.52^{\mathrm{bB}}$ & $82.60 \pm 7.91^{\mathrm{aA}}$ & $82.09 \pm 3.59^{\mathrm{abA}}$ & $80.92 \pm 4.61^{\mathrm{aA}}$ & $66.89 \pm 5.78^{\mathrm{abA}}$ & $15.27^{* * *}$ \\
\hline 20 & $40.33 \pm 4.12^{\mathrm{bc}}$ & $90.64 \pm 6.23^{\mathrm{aA}}$ & $93.13 \pm 1.41^{\mathrm{aA}}$ & $82.17 \pm 2.71^{\mathrm{AAB}}$ & $72.44 \pm 4.13^{\mathrm{abB}}$ & $27.04^{* * *}$ \\
\hline 40 & $57.24 \pm 2.71^{\mathrm{ac}}$ & $94.66 \pm 3.72^{\mathrm{aA}}$ & $94.59 \pm 2.15^{\mathrm{aA}}$ & $90.42 \pm 1.35^{\mathrm{aAB}}$ & $80.85 \pm 1.45^{\mathrm{aA}}$ & $47.34^{* * *}$ \\
\hline$F_{(4 ; 15)}$ & $106.53^{* * *}$ & $26.03^{* * *}$ & $65.27^{* * *}$ & $105.05^{* * *}$ & $122.33^{* * *}$ & \\
\hline
\end{tabular}

Mean \pm S.E. followed by the same capital letter in a line and the same lower letter in a column do not differ significantly at $P<0.05$ (Tukey's test) Each datum represents the mean of four replicates of 20 insects each

ns $P>0.05 ;{ }^{*} P<0.05 ;{ }^{* *} P<0.001 ; * * * P<0.0001$ 
14 days of exposure. Plectranthus glandulosus leaf powder induced low mortality (only $57.24 \%$ after 14 days at $40 \mathrm{~g} / \mathrm{kg}$ ) compared to the other products at all exposure periods. Low mortality rate was recorded at $5 \mathrm{~g} / \mathrm{kg}$ for the different powders. However, this lowest content (5 g/ $\mathrm{kg}$ ) induced significant mortality with increasing exposure time. The combinations 25PG75HA, 50PG50HA and $75 \mathrm{PG} 25 \mathrm{HA}$ at $5 \mathrm{~g} / \mathrm{kg}$ induced 8.75, 11.25 and $21.25 \%$, respectively, within 1-day exposure. However, the same combinations in the same order, at the same content level within 14-day exposure, provoked 68.13, 63.16 and $56.07 \%$ mortality of $S$. zeamais. According to the mortality rate, the different products can be ranked as follows: $H$. acida wood ash > 25PG75HA > 50PG50HA > 75PG52HA > Plectranthus glandulosus leaf powder.

\section{Toxicity and effect of the binary combinations}

The lethal content of different powders and their combinations reduced, when the exposure period increased (Table 5). The $\mathrm{LC}_{50}$ of P. glandulosus leaf powder was $213.64 \mathrm{~g} / \mathrm{kg}$ within 3 days, but it reduced to $28.65 \mathrm{~g} / \mathrm{kg}$ within 14 days. The $\mathrm{LC}_{50}$ of $H$. acida was 135.23 and $1.94 \mathrm{~g} / \mathrm{kg}$, respectively, within 3 days and 14 days. The same tendency was observed with the $\mathrm{LC}_{95}, \mathrm{H}$. acida wood ash recorded 190.82 and $38.34 \mathrm{~g} / \mathrm{kg} \mathrm{LC} \mathrm{L}_{95}$ values, respectively, within 7-day and 14-day exposure period. Between the 7th and 14th day after exposure, $\mathrm{LC}_{50}$ and $\mathrm{LC}_{95}$ values of the different combinations reduced with increasing exposure periods, respectively, from 18.17 to 3.04 and 458.17 to $416.35 \mathrm{~g} / \mathrm{kg}$ for 75PG25HA, 6.80 to 1.97 and 372.55 to $86.34 \mathrm{~g} / \mathrm{kg}$ for 50PG50HA and 10.82 to 2.18 and 928.12 to $33.77 \mathrm{~g} / \mathrm{kg}$ for 25PG75HA.

The combinations of P. glandulosus leaf powder with $H$. acida at different proportions produced different interactions. The combination made up by $75 \%$ of $P$. glandulosus leaf powder with $25 \%$ of $\mathrm{H}$. acida wood ash produced synergistic effect, whereas that made up by $50 \%$ each of two powders had antagonistic effect. The additive effect was observed at 14th day of exposure with 25PG75HA mixture.

\section{Reduction of progeny production}

The three combinations of $H$. acida and P. glandulosus significantly reduced the production of progeny compared to the control (Table 6). From the application of $5 \mathrm{~g} / \mathrm{kg}$ (lowest content), the number of emerging adults was highly reduced in treated samples (14.25 emerged adults) than in untreated ones (42.50 emerged adults).

\begin{tabular}{|c|c|c|c|c|c|c|c|}
\hline Products & Slope & $R^{2}$ & $\mathrm{LC}_{50}(95 \% \mathrm{FL})(\mathrm{g} / \mathrm{kg})$ & $\mathrm{LC}_{95}(95 \% \mathrm{FL})(\mathrm{g} / \mathrm{kg})$ & $\begin{array}{l}\text { Co-toxicity coef- } \\
\text { ficient (CTC) }\end{array}$ & $\begin{array}{l}\text { Significance } \\
\text { of CTC }\end{array}$ & $x^{2}$ \\
\hline \multicolumn{8}{|l|}{3 days } \\
\hline P. glandulosus & $0.980 \pm 0.253$ & 0.973 & $213.694(87.601 ; 2902)^{\mathrm{a}}$ & - & & & $1.523^{\text {ns }}$ \\
\hline H. acida & $0.569 \pm 0.199$ & 0.966 & $\begin{array}{l}135.326(50.483 \\
18,401)^{\mathrm{a}}\end{array}$ & - & & & $0.289^{\text {ns }}$ \\
\hline 75PG25HA & $0.728 \pm 0.193$ & 0.923 & $34.119(21.812 ; 99.052)$ & $6180(766.378 ; 4,210,605)^{a}$ & 547.111 & Synergistic & $0.622^{\text {ns }}$ \\
\hline 50PG50HA & $0.525 \pm 0.188$ & 0.924 & $25.278(14.683 ; 132.309)$ & $34,126\left(1340 ; 3.453 E^{12}\right)^{a}$ & 21.414 & Antagonistic & $0.349^{\text {ns }}$ \\
\hline 25PG75HA & $0.925 \pm 0.194$ & 0.904 & $24.774(17.920 ; 42.318)$ & $1485(377.425 ; 38,229)^{\mathrm{a}}$ & 601.378 & Synergistic & $1.342^{\text {ns }}$ \\
\hline \multicolumn{8}{|l|}{7 days } \\
\hline P. glandulosus & $0.908 \pm 0.231$ & 0.999 & $166.041(73.016 ; 1706)$ & - & & & $0.121^{\text {ns }}$ \\
\hline H. acida & $0.826 \pm 0.210$ & 0.988 & $1.946(0.280 ; 3.910)$ & $190.821(73.336 ; 3007)^{\mathrm{a}}$ & & & $0.323^{\text {ns }}$ \\
\hline 75PG25HA & $0.483 \pm 0.188$ & 0.848 & $18.166(9.275 ; 69.952)$ & $45,817\left(1355 ; 7.715 E^{15}\right)^{a}$ & 41.394 & Antagonistic & $0.564^{\mathrm{ns}}$ \\
\hline 50PG50HA & $0.946 \pm 0.195$ & 0.973 & $6.798(3.711 ; 9.538)$ & $372.549(138.058 ; 3695)^{a}$ & 56.589 & Antagonistic & $0.217^{\text {ns }}$ \\
\hline 25PG75HA & $0.851 \pm 0.191$ & 0.942 & $10.816(6.810 ; 15.197)$ & $928.122(249.182 ; 26,174)^{a}$ & 23.896 & Antagonistic & $0.545^{\mathrm{ns}}$ \\
\hline \multicolumn{8}{|l|}{14 days } \\
\hline P. glandulosus & $1.088 \pm 0.198$ & 0.976 & $28.645(21.379 ; 46.464)$ & $928.767(306.688 ; 9366)^{a}$ & & & $0.8263^{\text {ns }}$ \\
\hline H. acida & $1.268 \pm 0.249$ & 0.929 & $1.936(0.618 ; 3.316)$ & $38.341(25.041 ; 91.006)$ & & & $0.195^{\mathrm{ns}}$ \\
\hline 75PG25HA & $0.769 \pm 0.199$ & 0.981 & $3.036(0.605 ; 5.481)$ & $416.348(124.349 ; 15,575)^{a}$ & 212.073 & Synergistic & $0.085^{\mathrm{ns}}$ \\
\hline 50PG50HA & $1.00 \pm 0.222$ & 0.861 & $1.967(0.459 ; 3.634)$ & $86.344(44.754 ; 415.547)^{a}$ & 3.937 & Antagonistic & $0.986^{\mathrm{ns}}$ \\
\hline 25PG75HA & $1.381 \pm 0.255$ & 0.896 & $2.175(0.837 ;$ 3.509) & $33.773(23.036 ; 70.093)$ & 116.067 & Additive & $0.583^{\text {ns }}$ \\
\hline
\end{tabular}

ns $P>0.05 ; *: P<0.05$

a The LC values were obtained by extrapolation 
The progeny production inhibition ability might depend on the proportion of each botanical involved in the mixture, and thus, 2, 7 and 8 adults emerged, respectively, in grain treated with 25PG75HA, 50PG50HA and $75 \mathrm{PG} 25 \mathrm{HA}$ at the content of $40 \mathrm{~g} / \mathrm{kg}$. At $5 \mathrm{~g} / \mathrm{kg}$, 25PG75HA inhibited the $\mathrm{F}_{1}$ progeny production by more than $60 \%$, whereas 50PG50HA and 75PG25HA caused a reduction of less than $50 \%$. The higher inhibition rate of emerging insects was recorded at the highest content $(40 \mathrm{~g} / \mathrm{kg})$ of the three combinations, with $95.49,83.39$ and 80.92 reduction, recorded, respectively, for 25PG75HA, 50PG50HA and 75PG25HA. Overall, the combination 25PG75HA was revealed more effective than the two other (50PG50HA and 75PG25HA). This combination recorded the lowest $\mathrm{EC}_{50}(2.55 \mathrm{~g} / \mathrm{kg})$, whereas the highest $\mathrm{EC}_{50}(10.69 \mathrm{~g} / \mathrm{kg})$ was recorded for 75PG25HA (Tables 7 and 8).

\section{Suppression of population increase and reduction in grain damage}

All the treatments significantly reduced grain damage and population increase, compared to the control. The number of insects, grain damage and weight loss decreased when the concentration of powders increased. Concerning the different parameters, the difference was observed in terms of effectiveness according to the combination.
The number of insects was also considerably suppressed. Even at the lowest content $(5 \mathrm{~g} / \mathrm{kg})$, the three combinations revealed to be very effective; the grain treated with 25P75HA recorded 21.92 damaged grain and $3.22 \%$ weight loss, whereas the non-treated grain recorded 49.61 damaged grain and $12.81 \%$ weight loss. At their highest content level $(40 \mathrm{~g} / \mathrm{kg})$, the damage was almost completely suppressed. 25PG75HA revealed to be more effective compared to the other combinations; the grain treated with 25PG75HA recorded fewer insects than those treated with the two other combinations (50PG50HA, 75PG25HA). At $40 \mathrm{~g} / \mathrm{kg}, 26.50$ lived insects and 58.50 dead insects were counted from 25PG75HA treatment, whereas from 50PG50HA and 75PG25HA, 68 and 44.75 lived insects and 71.50 and 53.75 dead insects were recorded, respectively.

\section{Germination rate after 3 months of storage}

The germination rate varied with treatment. In general, the non-infested maize grain had a good germination rate than the infested ones. The germination rates from the non-infested treated grains did not varied amongst the treatments. However, these rates increased with ascending dosage with respect to treated infested grains. At $40 \mathrm{~g} / \mathrm{kg}, 97.50,95$ and $90 \%$ germination rates were recorded from the treatments 25PG75HA, 50PG50HA and 75PG25HA, respectively. Without insect, the germination was significantly higher even without insecticidal

Table 6 Progeny production of Sitophilus zeamais in maize treated with binary mixtures from Plectranthus glandulosus leaf powder with Hymenocardia acida wood ash under fluctuating laboratory conditions (temp. $=22.76 \pm 2.02{ }^{\circ} \mathrm{C}$; r.h. $=69.87 \pm 9.93 \%)$

\begin{tabular}{|c|c|c|c|c|}
\hline Content (g/kg) & 25PG75HA & 50PG50HA & 75PG25HA & $F_{(2 ; 9)}$ \\
\hline \multicolumn{5}{|c|}{ Mean number of $F_{1}$ adult progeny } \\
\hline 0 & $42.50 \pm 1.71^{\mathrm{aA}}$ & $42.50 \pm 1.17^{\mathrm{aA}}$ & $42.20 \pm 1.17^{\mathrm{aA}}$ & - \\
\hline 5 & $14.25 \pm 0.85^{\mathrm{bB}}$ & $23.00 \pm 2.86^{\mathrm{bAB}}$ & $28.50 \pm 4.65^{\mathrm{abA}}$ & $5.05^{*}$ \\
\hline 10 & $9.25 \pm 1.65^{\mathrm{bcB}}$ & $15.75 \pm 1.65^{\mathrm{bcAB}}$ & $23.75 \pm 3.79^{\mathrm{bA}}$ & $7.97^{*}$ \\
\hline 20 & $4.75 \pm 1.44^{\mathrm{cdB}}$ & $8.25 \pm 0.63^{\mathrm{cdAB}}$ & $14.50 \pm 3.80^{\mathrm{bcA}}$ & $4.34^{*}$ \\
\hline 40 & $2.00 \pm 0.82^{\mathrm{dB}}$ & $7.00 \pm 0.82^{\mathrm{dAB}}$ & $8.00 \pm 1.08^{\mathrm{cA}}$ & $12.40^{*}$ \\
\hline$F_{(4 ; 15)}$ & $145.94^{* * *}$ & $70.41^{* * *}$ & $16.23^{* * *}$ & \\
\hline \multicolumn{5}{|c|}{ Inhibition of adult emergence relative to control (\%) } \\
\hline 0 & $0.00 \pm 0.00^{\mathrm{dA}}$ & $0.00 \pm 0.00^{\mathrm{dA}}$ & $0.00 \pm 0.00^{\mathrm{dA}}$ & - \\
\hline 5 & $66.51 \pm 1.23^{\mathrm{CA}}$ & $45.92 \pm 6.42^{\mathrm{CAB}}$ & $33.27 \pm 10.56^{\mathrm{CB}}$ & $5.47^{*}$ \\
\hline 10 & $78.32 \pm 3.87^{\mathrm{bA}}$ & $62.88 \pm 3.97^{\mathrm{bAB}}$ & $44.53 \pm 8.27^{\mathrm{bcB}}$ & $8.66^{*}$ \\
\hline 20 & $88.91 \pm 3.47^{\mathrm{abA}}$ & $80.42 \pm 2.05^{\mathrm{aAB}}$ & $66.60 \pm 7.45^{\mathrm{aB}}$ & $5.31^{*}$ \\
\hline 40 & $95.49 \pm 1.74^{\mathrm{aA}}$ & $83.39 \pm 2.32^{\mathrm{aB}}$ & $80.92 \pm 3.17^{\mathrm{aB}}$ & $9.88^{*}$ \\
\hline$F_{(4 ; 15)}$ & $233.90^{* * *}$ & $86.76^{* * *}$ & $19.96^{* * *}$ & \\
\hline $\mathrm{EC}_{50}(95 \% \mathrm{FL}) \mathrm{g} / \mathrm{kg}$ & $2.553(1.291 ; 3.764)$ & $5.567(3.540 ; 7.390)$ & $10.694(6.741 ; 15.088)$ & \\
\hline
\end{tabular}

Mean \pm S.E. followed by the same capital letter in a line and the same lower case letter in a column do not differ significantly at $P<0.05$ (Tukey's test) ${ }^{*} P<0.05 ;{ }^{* * * P}<0.0001$ 
Table 7 Population increase in Sitophilus zeamais and grain damage recorded in stored maize treated with the binary combinations of wood ash of Hymenocardia acida with leaf powder of Plectranthus glandulosus under fluctuating laboratory conditions (temp. $=22.76 \pm 2.02{ }^{\circ} \mathrm{C} ;$ r.h. $=69.87 \pm 9.93 \%$ )

\begin{tabular}{|c|c|c|c|c|c|c|}
\hline \multirow[t]{2}{*}{ Content (g/kg) } & 25PG75HA & 50PG50HA & 75PG25HA & 25PG75HA & 50PG50HA & 75PG25HA \\
\hline & \multicolumn{2}{|c|}{ Number of lived insects } & \multicolumn{4}{|c|}{ Number of dead insects } \\
\hline 0 & $240.00 \pm 12.25^{\mathrm{a}}$ & $240.00 \pm 12.25^{a}$ & $240.00 \pm 12.25^{\mathrm{a}}$ & $50.50 \pm 8.53^{\mathrm{a}}$ & $50.50 \pm 8.53^{\mathrm{a}}$ & $50.50 \pm 8.53^{\mathrm{a}}$ \\
\hline 5 & $54.75 \pm 25.15^{\mathrm{b}}$ & $118.50 \pm 12.58^{b}$ & $170.00 \pm 7.07^{b}$ & $69.02 \pm 7.52^{\mathrm{a}}$ & $58.00 \pm 8.98^{\mathrm{a}}$ & $63.50 \pm 8.41^{\mathrm{a}}$ \\
\hline 10 & $36.50 \pm 4.56^{b}$ & $102.25 \pm 2.25^{b c}$ & $128.25 \pm 13.44^{b}$ & $69.00 \pm 1.35^{\mathrm{a}}$ & $62.02 \pm 2.71^{a}$ & $64.75 \pm 2.66^{\mathrm{a}}$ \\
\hline 20 & $38.75 \pm 7.18^{b}$ & $89.25 \pm 5.75^{\mathrm{bc}}$ & $72.75 \pm 2.53^{c}$ & $59.12 \pm 1.37^{\mathrm{a}}$ & $75.50 \pm 1.50^{\mathrm{a}}$ & $82.00 \pm 12.67^{a}$ \\
\hline 40 & $26.50 \pm 7.17^{b}$ & $68.00 \pm 10.00^{c}$ & $44.75 \pm 11.62^{c}$ & $58.50 \pm 0.96^{\mathrm{a}}$ & $71.50 \pm 2.50^{\mathrm{a}}$ & $53.75 \pm 5.54^{\mathrm{a}}$ \\
\hline \multirow[t]{2}{*}{$F_{(4 ; 15)}$} & $45.08^{* * *}$ & $51.25^{* * *}$ & $58.05^{* * *}$ & $2.32^{\mathrm{ns}}$ & $3.02^{\mathrm{ns}}$ & $2.22^{\mathrm{ns}}$ \\
\hline & \multicolumn{3}{|l|}{ Grain damage } & \multicolumn{3}{|l|}{ Weight loss (\%) } \\
\hline 0 & $49.61 \pm 4.54^{\mathrm{a}}$ & $49.61 \pm 4.54^{\mathrm{a}}$ & $49.61 \pm 4.54^{\mathrm{a}}$ & $12.81 \pm 1.49^{\mathrm{a}}$ & $12.81 \pm 149^{\mathrm{a}}$ & $12.81 \pm 1.49^{\mathrm{a}}$ \\
\hline 5 & $21.92 \pm 3.59^{b}$ & $28.02 \pm 1.55^{b}$ & $36.81 \pm 1.97^{b}$ & $3.22 \pm 0.82^{b}$ & $5.07 \pm 1.10^{\mathrm{b}}$ & $5.87 \pm 1.16^{b}$ \\
\hline 10 & $18.20 \pm 2.54^{b}$ & $25.13 \pm 1.43^{b}$ & $30.41 \pm 0.72^{b}$ & $3.02 \pm 1.36^{\mathrm{b}}$ & $4.15 \pm 0.91^{b}$ & $3.85 \pm 1.14^{b}$ \\
\hline 20 & $17.25 \pm 2.60^{b}$ & $20.12 \pm 3.01^{b}$ & $27.95 \pm 0.68^{b c}$ & $2.94 \pm 1.29^{b}$ & $3.92 \pm 1.00^{\mathrm{b}}$ & $3.43 \pm 0.23^{b}$ \\
\hline 40 & $13.56 \pm 1.17^{b}$ & $17.20 \pm 3.27^{b}$ & $17.60 \pm 2.00^{c}$ & $1.54 \pm 1.08^{\mathrm{b}}$ & $3.09 \pm 0.67^{b}$ & $2.79 \pm 0.62^{b}$ \\
\hline$F_{(4 ; 15)}$ & $22.25^{* * *}$ & $18.21 * * *$ & $23.68^{* * *}$ & $13.83^{* * *}$ & $13.86^{* * *}$ & $15.93^{* * *}$ \\
\hline
\end{tabular}

Mean \pm S.E. followed by the same capital letter in a line and the same lower case letter in a column do not differ significantly at $P<0.05$ (Tukey's test)

ns $P>0.05 ;{ }^{*} P<0.05 ; * * * P<0.0001$

Table 8 Germination of stored grains treated with binary combinations of Hymenocardia acida wood ash with Plectranthus glandulosus leaf powder and infested, and non-infested by Sitophilus zeamais under laboratory conditions (temp.: $22.76 \pm 2.02{ }^{\circ} \mathrm{C} ;$ r.h. $\left.=69.87 \pm 9.93 \%\right)$

\begin{tabular}{|c|c|c|c|c|c|c|}
\hline \multirow[t]{3}{*}{ Content (g/kg) } & \multicolumn{6}{|l|}{ Products } \\
\hline & 25PG75HA & 50PG50HA & 75PG25HA & 25PG75HA & 50PG50HA & 75PG25HA \\
\hline & \multicolumn{3}{|l|}{ Non-infested } & \multicolumn{3}{|l|}{ Infested } \\
\hline 0 & $94.33 \pm 1.36^{\mathrm{a}}$ & $94.33 \pm 1.36^{\mathrm{a}}$ & $94.33 \pm 1.36^{a}$ & $21.67 \pm 2.15^{d}$ & $21.67 \pm 2.15^{d}$ & $21.67 \pm 2.15^{c}$ \\
\hline 5 & $91.08 \pm 0.21^{\mathrm{a}}$ & $90.83 \pm 1.50^{\mathrm{a}}$ & $94.83 \pm 1.90^{a}$ & $84.67 \pm 0.83^{c}$ & $81.67 \pm 3.19^{c}$ & $78.33 \pm 0.96^{b}$ \\
\hline 10 & $92.00 \pm 0.79^{a}$ & $94.50 \pm 1.83^{\mathrm{a}}$ & $92.83 \pm 0.88^{a}$ & $88.33 \pm 1.67^{b c}$ & $84.17 \pm 2.50^{b c}$ & $83.33 \pm 1.36^{a b}$ \\
\hline 20 & $92.17 \pm 0.74^{a}$ & $94.17 \pm 1.50^{\mathrm{a}}$ & $93.42 \pm 1.64^{a}$ & $92.33 \pm 0.83^{\mathrm{ab}}$ & $93.33 \pm 1.36^{a}$ & $86.67 \pm 2.36^{a b}$ \\
\hline 40 & $91.17 \pm 0.32^{a}$ & $92.08 \pm 0.79^{a}$ & $92.20 \pm 1.73^{\mathrm{a}}$ & $97.50 \pm 1.60^{\mathrm{a}}$ & $95.00 \pm 1.67^{\mathrm{a}}$ & $90.00 \pm 2.36^{a}$ \\
\hline$F_{(4 ; 15)}$ & $2.72^{\text {ns }}$ & $1.30^{\text {ns }}$ & $0.41^{\mathrm{ns}}$ & $430.01^{* * *}$ & $180.43^{* * *}$ & $218.78^{* * *}$ \\
\hline
\end{tabular}

Mean \pm S.E. followed by the same capital letter in a line and the same lower case letter in a column do not differ significantly at $P<0.05$ (Tukey's test)

powder (94.33\%), whereas with insect the germination rate was very low (21.67\%).

\section{Discussion}

The binary mixtures of $P$. glandulosus leaf powder and $H$. acida wood ash provoked significant mortality of $S$. zeamais. The different binary combinations of these two substances produced different effects such as synergism, antagonism and additivity. The combination of insecticidal materials has the advantages to increase efficacy by complementing the bio-efficacy of the individual products and simultaneously lowering their doses on the one hand, and broadening the spectrum of activity and reducing the chance of resistance development on the other hand [33]. However, with mixtures, negative effects can also occur such as reduced efficacy, phyto-toxicity and incompatibility problems between materials [34]. The combinations of $75 \%$ of P. glandulosus leaf powder and $25 \%$ of $H$. acida on S. zeamais mortality produced synergistic effect, whereas combination made up by $50 \%$ of P. glandulosus leaf and 50\% $\mathrm{H}$. acida wood ash induced antagonistic effect within 14 days, which produced a significant synergism. In general, the mixtures composed by the individual insecticidal materials improved in efficacy. The additive effect was also observed; the effect of two materials is equal to the sum of each component 
given alone $(1+3=4)$, which was observed in the present study by the combination 25PG75HA (25\% P. glandulosus leaf powder and $75 \% \mathrm{H}$. acida wood ash) within 14 days of exposure.

The synergism has been demonstrated in this experiment by the decreasing $\mathrm{LC}_{50}$ values compared to those of single material. The proportions of two products used in combinations may produce different performances according to the involved proportions. The combinations of 75PG25HA and 50PG50HA produced, respectively, synergistic and antagonistic effect. The same tendency concerning the variations in efficacy for different proportions of products was observed by Ntonifor et al. [35]. They found that the combinations of Syzygium aromaticum (L.) (Myrtaceae) and Cyperus aequalis (Vahl) (Cyperaceae) at the proportions of 0:2, 0.5:1.5, 1:1, 2:0 (g:g) induced 36.3, 93.8, 98.8, 100\% mortality of C. maculatus, respectively, within 3 days of exposure. Shaalan et al. [36] found that mixtures of Khaya senegalensis A. Juss (Meliaceae) and Daucus carota Linnaeus (Apiaceae) seed extracts were more effective and economical than phytochemicals alone in controlling Aedes aegypti Linnaeus (Diptera: Culicidae) and Culex annulirostris Skuse (Diptera: Culicidae) mosquitoes.

The three binary combinations of $P$. glandulosus leaf powder and $H$. acida wood ash considerably inhibited the production of $S$. zeamais progeny. In addition to increasing mortality, the combinations of these products have an effect on the development of S. zeamais. The presence of P. glandulosus leaf powder in combinations may potentiate the effect of ash. There are physical and chemical actions, which are the desiccation by ash and poisoning by the chemical compounds contained in P. glandulosus leaf. Mixtures can disturb or delay the development of larvae in adults. Karso and $\mathrm{Al}$ Mallah [37] found that the mixture of soya oil and Acetamiprid pesticide gave the highest average mortality of Trogoderma granarium larvae, which varied according to the proportions.

The combinations of insecticidal materials improve the protection of stored grain by reducing the qualitative and quantitative losses. The reduction in damage and the suppression of $S$. zeamais population growth were positively correlated. Combinations of $\mathrm{H}$. acida wood ash and P. glandulosus leaf powder at different proportions considerably reduced damage, by lowering the number of perforated grains and weight loss, and at the same time by inhibiting the population increase. Hill [38] reported that wood ash was useful as a physical barrier on the grain. However, it can also possess various chemical properties according to its botanical source. Plectranthus glandulosus leaf, thanks to its chemical compounds, controlled the proliferation of insect, which explains the efficacy of combinations in short storage period. When the storage period increased, the efficacy decreased by loss of their volatile compounds which confer its toxicity against insects. Similar findings were reported by Mwangangi and Mutsiya [39], who showed that the efficacy of Ocimum basilicum Linnaeus (Lamiaceae) powder deteriorated the fastest leading to 80, 77, 44, 20 and 15\% mortality over $0,7,14,21$ and 28 days of storage. Then, to improve effectiveness of ash plant powders combinations and allow components to ensure a good preservation of grains, it is important to avoid the increase in moisture.

In many African countries, stored grains provide not only grains for food, but also seeds for planting. Thus, the conservation of seed viability after the application of protectant is necessary. During the experiment, in the presence of weevils, germination rate increased with increase in product contents. The untreated maize in the presence of insects recorded the week germination rate. In this case, the seed loses their germination ability due to the high $S$. zeamais infestation that lays its eggs on grain. The larvae develop and feed inside the grain by consuming the germ of the seed, thus diminishing the viability of the seeds. Usha Rani and Devanand [40] found that seed germination was significantly reduced when untreated maize seeds were exposed to S. oryzae and T. castaneum. But when the maize seeds were stored with combinations of P. glandulosus leaf powder and wood ash without weevils, no difference was observed amongst treatments and content levels and they conserved significant germination rate. Higher levels of the products improved their ability to protect grain, leading to a greater germination capacity. The different powders did not present any adverse effect on maize seed germination. It has been shown that the storage of maize seeds for prolonged periods after treatment with various botanical concentrations does not have any adverse effect on the seed viability.

In the present study, no adverse effect was observed on germination ability. But, some findings reported the inhibiting effect of some plant extracts on seed germination [41, 42]. The application of lower concentrations of Murraya koenigii Linnaeus (Rutaceae) and Capsicum annuum Linnaeus (Solanaceae) extracts caused a normal germination, but the same plants at higher concentrations caused $30-35 \%$ inhibition of seed germination. Bustos-Figueroa et al. [42] observed that the leaf powder of $P$. boldus used alone or mixed with lime did not affect the percentage of maize seed germination. This corroborates our findings about the germination rate recorded with the treatments. Higher germination rate recorded by the combinations of $25 \%$ of $P$. glandulosus leaf powder and $75 \%$ of wood ash could be due to the higher content of ash in the combination. According to Philogène [43], the ash does not affect germination but could enhance growth because of the cations that it contains. H. acida 
wood ash contains high quantity of $\mathrm{Ca}, \mathrm{K}, \mathrm{P}, \mathrm{Na}$ and $\mathrm{Fe}$, which are important for plant growth. Parimelazhagan and Francis [44] found that leaf extracts of Cerastium viscosum Linnaeus (Caryophyllaceae) increased seed germination and improved seedling development of rice seeds. In general, grains in storage facilities lost their viability and germination chances as the post-harvest storage period increases [45]. That could explain the loss of viability partly even when the seeds do not have damage. The combinations protected the maize grains against the destruction of their germination capacity by weevils, and they did not influence negatively seed germination.

\section{Conclusions}

The binary combinations of $P$. glandulosus leaf powder and $H$. acida wood ash at different proportions effectively protect maize grain against infestation by $S$. zeamais in storage. The binary combinations did not alter the viability of maize grains, and thus, the germination rate. The beneficial effect of the combinations could be enhanced by using the appropriated proportions. Other proportions which may be involved in the mixture of these botanicals may be tested in order to the find out the most appropriate efficient combination. Further studies need to be carried out concerning mammalian toxicity that could be attributed to the use of these products in grain storage. Also, the investigations need to be undertaken in order to assess the effect of these powders on the organoleptic and technological properties of treated grains.

\section{Abbreviations \\ 25PG75HA: 25\% Plectranthus glandulosus leaf powder + 75\% Hymenocardia acida wood ash; 50PG50HA: 50\% Plectranthus glandulosus leaf powder $+50 \%$ Hymenocardia acida wood ash; 75PG25HA: 75\% Plectranthus glandulosus leaf powder $+25 \%$ Hymenocardia acida wood ash; temp.: temperature; r.h.: relative humidity; LC: lethal content; EC: efficacy content; $d$ f: degree of freedom; FL: fudicial limit.}

\section{Authors' contributions}

JWG, ENN and DN conceived the idea, designed the experiments and analysed the data. JWG, CS and TG carried out the experiments. JWG wrote the manuscript. All authors read and approved the final manuscript.

\section{Author details}

${ }^{1}$ Department of Biological Sciences, Faculty of Science, University of Bamenda, P.O. Box 39, Bambili, Cameroon. ${ }^{2}$ Department of Biological Sciences, Faculty of Science, University of Ngaoundere, P.O. Box 454, Ngaoundere, Cameroon. ${ }^{3}$ Coordination of Annual Crops, IRAD Nkolbisson, P.O. Box 2123, Yaoundé, Cameroon.

\section{Acknowledgements}

The authors are thankful to the laboratory of soil analysis and environmental chemistry of the faculty of Agronomic Sciences of the University of Dschang (Cameroon) for the analysis of wood ash mineral content and the Research Institute on Medicinal Plants (IMPM) of Yaoundé for the extraction of essential oils and the determination of its volatile constituents using GC-MS. They also express their gratitude to IRAD (Institute of Agricultural Research for Development) Bambui (Cameroon) for providing facilities to carry out this research work.

\section{Competing interests}

The authors declare that they have no competing interests.

\section{Availability of data and materials}

The data sets used and/or analysed during this study are available from the corresponding author on reasonable request.

\section{Consent for publication}

Not applicable.

Ethics approval and consent to participate

Not applicable.

\section{Funding}

Not applicable.

\section{Publisher's Note}

Springer Nature remains neutral with regard to jurisdictional claims in published maps and institutional affiliations.

Received: 5 September 2017 Accepted: 21 March 2018

Published online: 03 April 2018

\section{References}

1. Koehler P, Wieser H. Chemistry of cereal grains. In: Gobbetti M, Gänzle $M$, editors. Handbook on sourdough biotechnology. New York: Springer; 2013. https://doi.org/10.1007/978-1-4614-5425-0_2.

2. FAO, Maize: International Market Profile. FAO/O.N.U. Rome. 2006.

3. Gwinner J, Harnish R, Muck O. Manual on the prevention of postharvest grain loss. Eschborn: GTZ; 1996.

4. Ngamo TSL, Hance T. Diversité des ravageurs des denrées et méthodes alternatives de lutte en milieu tropical. Tropicultura. 2007;25:215-20.

5. Subramanyam Bh, Hagstrum D. Resistance measurement and management. In: Subramanyam Bh, Hagstrum D, editors. Integrated management of insects in stored products. New York: Marcel Dekker; 1995. p. 231-398.

6. Park IK, Lee SG, Choi DH. Insecticidal activities of constituents identified in the essential oil from leaves of Chamaecyparis obtusa against Callosobruchus chinensis (L.) and Sitophilus oryzae (L.). J Stored Prod Res. 2003:39:375-84.

7. Ngamo TSL, Ngantanko I, Ngassoum MB, Mapongmetsem PM, Hance T. Insecticidal efficiency of essential oils from 5 aromatic plants tested both, alone and in combination towards Sitophilus oryzae (L.) (Coleoptera: Curculionidae). Res J Biol Sci. 2007;2:75-80.

8. Nukenine EN, Adler C, Reichmuth Ch. Efficacy evaluation of plant powders from Cameroon as post-harvest grain protectants against the infestation of Sitophilus zeamais Motchulsky (Coleoptera: Curculionidae). J Plant Dis Prot. 2007:114:30-6.

9. Nukenine EN, Adler C, Reichmuth Ch. Bioactivity of fenchone and Plectranthus glandulosus oil against Protephanus truncatus and two strains of Sitophilus zeamais. J Appl Entomol. 2010;134:132-41.

10. Mulungu LS, Kubala MT, Mhamphi GG, Misangu R, Mwatawala MW. Efficacy of protectants against maize weevils (Sitophilus zeamais Motschulsky) and the larger grain borer (Prostephanus truncatus Horn) for stored maize. Int Res J Plant Sci. 2010;1:150-4.

11. Moyin-Jesu El. Comparative evaluation of modified neem leaf, neem leaf and wood ash extracts as pest control in maize (Zea mays L). Emir J Food Agric. 2010;22:34-44.

12. Singh SR. Bioecological studied and control of pulse bettle Callasobruchus chinensis (Coleoptera: Bruchidae) on cowpea seed. Adv Appl Sci Res. 2011;2:295-302.

13. Ntonifor NN, Forbanka DN, Mbuh JV. Potency of Chenopodium ambrosioides powders and its combinations with wood ash on Sitophilus zeamais in stored maize. J Entomol. 2011:8:375-83.

14. Ngassoum MB, Jirovetz L, Buchbauer G, Fleischlacker W. Investigation of essential oils of Plectranthusglandulosus Hook. (Lamiacée) from Cameroon. J Essent Oil Res. 2001;13:73-5. 
15. Ngamo TSL, Ngassoum MB, Mapongmestsem PM, Noudjou WF. Use of essential oils of plants as protectant of grains during storage. Agric J. 2007;2:204-9.

16. Goudoum A, Ngamo TLS, Ngassoum MB, Tatsadjieu LN, Mbofung CM. Tribolium castaneum (Coleoptera: Curculionidae) sensitivity to repetitive applications of lethal doses of imidacloprid and extracts of Clausena anisata (Rutaceae) and Plectranthus glandulosus (Lamiaceae). Int J Biol Chem Sci. 2010;4:1242-50.

17. Nukenine EN, Adler C, Reichmuth Ch. Efficacy of Clausena anisata and Plectranthus glandulosus leaf powder against Prostephanus truncatus (Coleoptera: Bostrichidae) and two strains of Sitophilus zeamais (Coleoptera: Curculionidae) on maize. J Pest Sci. 2010;83:81-90.

18. Golob P, Mwambula J, Mhango V, Ngulube F. The use of locally available materials as protectants of maize grain against insect infestation during storage. J Stored Prod Res. 1982;18:67-74.

19. Firdissa E, Abraham T. Effect of some botanicals and other materials against the maize weevil Sitophilus zeamais, Motschulsky on stored maize. In: Bent T, editor, Maize production technology for the future: challenge and opportunities. Proceedings of the sixth eastern and southern Africa regional maize conference, 21-25 September 1998, Addis Ababa, Ethiopia. 1999; p. 101-4.

20. Akob AC, Ewete KF. The efficacy of ashes of four locally used plant materials against Sitophilus zeamais (Coleoptera: Curculionidae) in Cameroon. Int J Trop Insect Sci. 2007;27:21-6.

21. Oguntade TO, Adekunle AA. Preservation of seeds against fungi using wood-ash of some tropical forest trees in Nigeria. Afr J Microbiol Res. 2010:4:279-88

22. Gemu M, Getu E, Yosuf A, Tadess T. Management of Sitophilus zeamais Motshulsky (Coleoptera: Ciurculionidae) and Sitotroga cerealella (Olivier) (Lepidoptera: Gelechidae) using locally available inert materials in Southern Ethiopia. Greener J Agric Sci. 2013;3(6):508-15.

23. Mc Lafferty FW, Stauffer DB. Wiley registry of mass spectral data, 6 th ed. Mass spectrometry library search system BenchTop/PBM, version 3.10d. Newfield: Palisade Co.; 1994.

24. König WA, Hochmuth DH, Joulain D. Terpenoids and related constituents of essential oils. Hamburg: Institute of Organic Chemistry, University of Hamburg; 2001.

25. Pauwels JM, Van Ranst AE, Verloo M, Mvondo Ze A. Manuel de laboratoire de pédologie: Méthodes d'analyses de sols et de plantes, équipement, gestion de stocks de verrerie et de produits chimiques AGCD et Centre Universitaire de Dschang. Bruxelles: Royaume de Belgique; 1982.

26. Sun Y-P, Johnson ER. Synergistic and antagonistic actions of insecticide synergist combinations and their mode of action. J Agric Food Chem. 1960;8:261-6.

27. Adams JM, Schulten GGM. Loss caused by insects, mites and microorganisms. In: Harris KL, Lindblad CJ, editors. Post-harvest grain loss assessment methods. St. Paul: American Association of Cereal Chemists; 1978. p. 83-95.
28. Rao NK, Hanson J, Dulloo ME, Ghosh K, Nowell D, Larinde M. Manuel de manipulation des semences dans les banques de gènes. Manuels pour les banques de gènes No. 8. Rome: Bioversity International; 2006.

29. Zar JH. Biostatistical analysis. 4th ed. Upper Saddle River: Prentice-Hall; 1999.

30. SAS Institute. The SAS Sysrem version 9.1 for windows. SAS Institute, Cary. NC; 2003.

31. Finney DJ. Probit analysis. London: Cambridge University Press; 1971.

32. Abbot WA. Method of computing the effectiveness of an insecticide. J Econ Entomol. 1925;18:265-7.

33. Das SK. Scope and relevance of using pesticide mixtures in crop protection: a critical review. Int J Environ Sci Toxicol Res. 2014;2:119-23.

34. Regupathy A, Ramasubramanian T, Ayyasamy R. Rational behind use of pesticide mixtures for management of resistant pest in India. J Food Agric Environ. 2004;2:278-84.

35. Ntonifor NN, Oben EO, Konje CB. Use of selected plant-derived powders and their combinations to protect stored cowpea grains against damage by Callosobruchus maculatus. ARPN J Agric Biol Sci. 2010;5(5):13-21.

36. Shaalan EAS, Canyon DV, Younes MWF, Abdel-Wahab H, Mansour A-H. Synergistic efficacy of botanical blends with and without synthetic insecticides against Aedes aegypti and Culex annulirostris mosquitoes. J Vector Ecol. 2005;30:284-8.

37. Karso BA, Al Mallah NM. Effect of mixing ratio and oil kind on toxicity activation of Acetamprid against Trogoderma granarium larvae. IOSR J Pharm. 2014;4:35-40

38. Hill DS. Pests of stored products and their control. London: Belhaven Press; 1990. p. 206-61.

39. Mwangangi BM, Mutisya DL. Performance of basil powder as insecticide against maize weevil, Sitopillus zeamais (Coleoptera: Curculionidae). Discourse J Agric Food Sci. 2013;1(11):196-201.

40. Usha Rani P, Devanand P. Efficiency of different plant foliar extracts on grain protection and seed germination in maize. Res J Seed Sci. 2011;4(1):1-14

41. Chung IM, Miller DA. Natural herbicide potential of alfalfa residue on selected weed species. Agron J. 1995:87:920-5.

42. Bustos-Figueroa G, Osses-Ruiz F, Silva-Aguayo G, Tapia-Vargas M, HeppGallo R, Rodriguez-Maciel JC. Insecticidal properties of Peumus boldus Molina powder used alone and mixed with lime against Sitophilus zeamais Motschulsky (Coleoptera: Curculionidae). Chil J Agric Res. 2009:3:350-5.

43. Philogène BJ. Volcanic ash for insect control. Can Entomol. 1972;104:1487.

44. Parimelazhagan T, Francis K. Antifungal activity of Clerodendrum viscosum against Curvularia lunata in rice seeds. J Mycol Plant Pathol. 1999;29:139-41.

45. Hedimbi M, Ananias NK, Kandawa-Schulz M. Effect of storage conditions on viability, germination and sugar content of pearl millet (Pennisetum glaucum) grains. J Res Agric. 2012;1:088-92.

\section{Submit your next manuscript to BioMed Central and we will help you at every step:}

- We accept pre-submission inquiries

- Our selector tool helps you to find the most relevant journal

- We provide round the clock customer support

- Convenient online submission

- Thorough peer review

- Inclusion in PubMed and all major indexing services

- Maximum visibility for your research

Submit your manuscript at www.biomedcentral.com/submit 